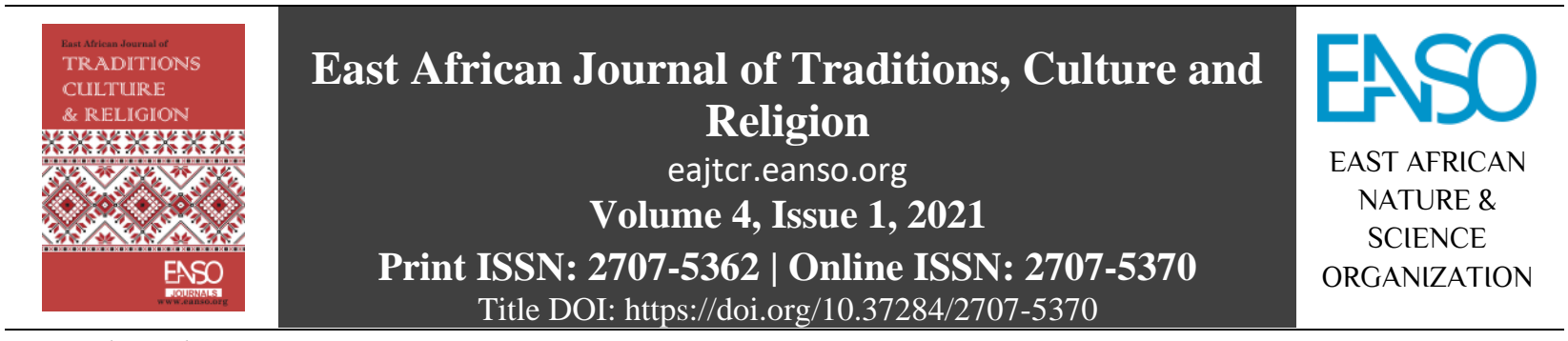

Original Article

\title{
An Anthropological Discourse to Christian Views on Polygamy and Plural Relationships in Uganda.
}

\author{
Tabitha Naisiko ${ }^{{ }^{*}}$ \\ ${ }^{1}$ Department of Development Studies, Makerere University, P. O. Box 7072, Kampala, Uganda. \\ * Author for Correspondence ORCID ID: https://orcid.org/0000-0001-9136-6611; Email: naisiko@ gmail.com
}

Article DOI: https://doi.org/10.37284/eajtcr.4.1.558

\section{Date Published: ABSTRACT}

06 November 2021 Marriage and family are prominent institutions in society because they define a person's essence of life and identity, through providing means and conditions for

Keywords: survival, participation and sustenance. Marriage thus has forms that are inclusive, given the social realities in an area. However, as society changes, we realise that

Marriage, the institution is also changing to respond to new anthropological demands. This Anthropological paper deals with the polygamous form of marriage and the accruing transitions as

Discourse, well as tensions in this institution. The paper gives a cross sectional analysis of

Christian Views, the phenomenon, discussing its continuities and discontinuities. The paper is

Plural regulate the institution of marriage to be inclusive. In order to discuss the

Relationships, surrounding tensions, the discussion will concern polygamy and Plural

Uganda. relationships based on situation analysis in Uganda, personal reflections, literature and field data.

\section{APA CITATION}

Naisiko, T. (2021). An Anthropological Discourse to Christian Views on Polygamy and Plural Relationships in Uganda. East African Journal of Traditions, Culture and Religion, 4(1), 8-15. https://doi.org/10.37284/eajtcr.4.1. 558

\section{CHICAGO CITATION}

Naisiko, Tabitha. 2021. "An Anthropological Discourse to Christian Views on Polygamy and Plural Relationships in Uganda". East African Journal of Traditions, Culture and Religion 4 (1), 8-15. https://doi.org/10.37284/eajtcr.4.1. 558.

\section{HARVARD CITATION}

Naisiko, T. (2021) "An Anthropological Discourse to Christian Views on Polygamy and Plural Relationships in Uganda", East African Journal of Traditions, Culture and Religion, 4(1), pp. 8-15. doi: 10.37284/eajtcr.4.1.558.

\section{IEEE CITATION}

T. Naisiko, "An Anthropological Discourse to Christian Views on Polygamy and Plural Relationships in Uganda", EAJTCR, vol. 4, no. 1, pp. 8-15, Nov. 2021.

8 | This work is licensed under a Creative Commons Attribution 4.0 International License. 


\section{MLA CITATION}

Naisiko, Tabitha. "An Anthropological Discourse to Christian Views on Polygamy and Plural Relationships in Uganda". East African Journal of Traditions, Culture and Religion, Vol. 4, no. 1, Nov. 2021, pp. 8-15, doi:10.37284/eajtcr.4.1.558.

\section{INTRODUCTION}

Marriage and family are prominent institutions in society because they define a person's essence of life and identity, through providing means and conditions for survival, participation and sustenance. Marriage thus has forms that are inclusive, given the social realities in an area. However, as society changes, we realise that the institution is also changing to respond to new anthropological demands. This paper deals with the polygamous form of marriage and the accruing transitions as well as tensions in this institution. The paper gives a cross sectional analysis of the phenomenon, discussing its continuities and discontinuities. The paper is aimed at highlighting the anthropological basis of marriage so that society may not judge people at the periphery, but support and understand them as well as regulate the institution of marriage to be inclusive. In order to discuss the surrounding tensions, the discussion will concern polygamy and Plural relationships based on situation analysis in Uganda, personal reflections, literature and field data.

\section{Defining Polygamy and Highlighting Related Tensions}

Polygamy is a form of marriage where one person has more than one spouse. According to Micheal Haward and Janet Dunaif-Hattis, polygamy has two principal types; these being, polygyny where one man has more than one woman and polyandry where one woman has more than one man at the same time ${ }^{1}$. Traditionally, African families are polygynous where it is the man who has more than one wife. With social-economic changes that are affecting gender dynamics, present societies are

1 Micheal Haward and Janet Dunaif-Hattis, Anthropology: Understanding Human Adaptation (New York: HarperCollins Publishers Inc, 1992), 453-455.

2 Jack Goody, Production and Reproduction: A Comparative Study of the Domestic Domains (Cambridge: Cambridge University Press 1976), 4246. witnessing polyandrous relationships as well. However, socially accepted and legally defined relations are those of polygyny where a man has more than one woman. In Africa, polygamy is affirmed as an authentic form of marriage upon the family of the groom paying bride price to family of the bride. This then becomes the stamp of approval for a marriage and legitimates the procreation of children. Until bride price is paid, neither marriage nor polygamy is named. After which, regardless of her serial number, the bride, is recognized as a wife with all accruing rights and responsibilities. These include being a mother to all the children of her husband. Thus, according to Jack Goody, there are no concubines, stepmothers and stepchildren in Africa because all these are entitled to the estates of the husband through payment of bride price ${ }^{2}$.

In the laws of Uganda, the forms of marriage recognised as authentic are civil marriage, church (Christian-based) marriage, Sharia marriage for Muslims and customary marriages. The first two are predominantly monogamous. Whoever marries under those two must remain in monogamous and subsequent marriages will be null and void $^{3}$. A person who contemplates being polygamous should go for customary marriage because this will allow him to perform authentic subsequent marriages under the law. In this case, polygamy is a legally defined concept that should not be used elusively to mean someone in plural relationships. However, the reality in contemporary society is that, whether under the law or not, when a man consistently has sexual relationship with a woman and has children, she will always be considered his "wife" regardless of the official marriage requirements. In this paper, the term plural relationships will be used to include

${ }^{3}$ The Marriage Act Cap 251(1904) which is the current law on contracting marriages in Uganda provides under Section 10(d) that neither of the parties to the intended marriage is married by customary law to any person other than the person with whom such marriage is proposed to be contracted.

9 | This work is licensed under a Creative Commons Attribution 4.0 International License. 
couples with multiple sexual partners living together but not officially married.

While polygamy is sanctioned by my Kisoga culture since time immemorial ${ }^{4}$, my Christened African community refutes it. Despite cases of polygamy in the Bible like David (1 Samuel 25:40-43), Solomon and Jacob (Genesis 29:15-30), Elkanah (1Samuel 1:2), Christianity emphasises monogamy. I have been brought up and socialised in a community with double royalty. I have hence grown to respect people in polygynous marriages, but at the same time have grown to detest the practice because of the observable problems as well as propaganda around it. On the other hand, I have grown up to sympathise with the women in polygynous relationships because they courageously stay despite the challenges of economic hardships, physical attacks, sexually transmitted diseases, suspicions and fears of witchcraft. A wife in a polygamous marriage or a woman in a plural relationship is respected. Moreover, single mothers, concubines and spinsters are ridiculed. This implies the value of marriage in society.

The contradictory feelings about polygamy are not limited to me but several people in my time. Polygamy thus is embraced or judged on a continuum of pride and shame, elite and illiterate, rich and poor, haves and have-nots of power, men and women, Christian and non-Christian, traditional and modern. Literature about polygamy too do not give a conclusive opinion as to whether polygyny is adorable or detestable. With the embrace of Christianity, formal education, professionalism, legal practices, etc, polygamy as a form of marriage has been compromised and open to ridicule. Consequently, with the inevitability of marriage and its benefits, people have now resorted to illegitimate plural relationships in form of concubinage and single parenthood. This puts some members' psycho-social needs at the margins and it thus has anthropological implications as far as the African communities are concerned.

${ }^{4}$ William Blum, Forms of Marriage: Monogamy Reconsidered (Nairobi: AMECEA Gaba Publications, 1989), 22-27. Blum, p. 3 says polygyny was found by the first missionaries to visit Africa in

\section{Anthropological Needs as Anchored in Polygamy and Plural Relationships}

According to Aylward Shorter, general anthropology is the study of all aspects of human beings. Breaking the discipline into taxonomies, he classifies it as follows:

- Physical anthropology which is the study of the human body, genetics, blood group and human evolution

- Psychology which is the study of the conscious and unconscious mind

- Social-cultural anthropology which studies humans in society

- Social psychology which studies psychological response to the environment

- Science of culture which studies the learned aspects of human behaviour

- Social sciences which is the study of social relationships

- Cultural anthropology which studies the whole cultures and learning theory

- Ethnology which studies the material culture, economy, links with economics and human geography

- Social anthropology which studies small scale relationships and put emphasis on ideas

- Sociology which studies large scale relationships and emphasises on behaviour ${ }^{5}$

Based on the above, we can sum up that a human being is never an isolated entity, his/her essence is based on the general environment as dictated anthropologically. Therefore, human beings thrive in anthropologically grounded institutions such as marriage and family in order to bring out the essence of humanity. Not far from Aylward Shorter, for

the latter part of the fourteenth century, as well as by those who visited the New World.

5 Aylward Shorter, African Culture: An Overview (Nairobi: Pauline Publication Africa, 2001)10.

10 This work is licensed under a Creative Commons Attribution 4.0 International License. 
Bodley, anthropologists study all aspects of human life through examination of how people live, what they think, what they produce and how they interact with their environments. ${ }^{6}$ This helps in learning how people meet day-to-day needs and plan how-to livein future. On this note, Micheal Haward and Janet Dunaif-Hattis argue that among humans, the interaction between men and women involves more than occasional sexual encounters and sharing food. Male-female relationships are in fact an integral part of most aspects of social life. Thus, every human society has developed institutions to regulate these relations, two of the most universal being marriage and family. ${ }^{7}$ The near universality of marriage in human society is related to mastering several problems common to the human species. Thus, marriage is a problem-solving institution that provides for child production and upbringing, intimate and sexual needs, division of labour based on gender, formation of social, economic and political alliances. ${ }^{8}$ In agreement, David Brinkerhoff and Lynn White add that the family is also aimed for the ascription of status, provision of intimacy, belongingness and emotional support. In families and societies in which wealth, property, or a hereditary title is to be passed on from one generation to the next, inheritance and the production of legitimate heirs are a prime concern in marriage 9 .

By being exclusive and pushing people to the periphery, the Ugandan laws on marriage are not anthropologically grounded. Perhaps it is for this reason that most Ugandans are not married if we took a legal definition. Research has it that $64.6 \%$ of the couples are living in intimate relationships which are not legally defined ${ }^{10}$. This then causes another tension of legality whereby women in a

${ }^{6}$ Bodley, John H. "Anthropology." Microsoft® Student 2009

[DVD]. Redmond, WA: Microsoft Corporation, 2008.

7 Micheal Haward and Janet Dunaif-Hattis, Anthropology: Understanding Human Adaptation (New York: HarperCollins Publishers Inc, 1992), 449.

${ }^{8}$ Micheal Haward and Janet Dunaif-Hattis, Anthropology: Understanding Human Adaptation (New York: HarperCollins Publishers Inc, 1992), 465.

${ }^{9}$ David Brinkerhoff and Lynn White, Essentials of sociology, (New York: West Publishing Company, 1989),208.

${ }^{10}$ In a sample of 555 women interviewed in central Uganda, Charles Lwanga discovered that $64.2 \%$ were still cohabiting... by the end of the third year $87 \%$ of the women patriarchal society cannot force men into official marriage. Religion which enforces monogamy onto its followers has aggravated this problem. Consequently, many women live at the periphery of marriages in form of intimate relationships for the rest of their lives. In this case, they can easily be disposed out of their homes without claims because the law does not protect them. It only does to the legal wife/wives and the children.

The tension above can enable us visualize that polygyny has a lot of implications as far as human relations and survival are concerned. They include; patriarchy systems, gender issues, economic matters, legal matters, religious and anthropological matters. On this note, it would be unfair to discuss polygamy and plural relationships when isolating it from the broader cultural context ${ }^{11}$. Therefore, to encourage or discourage polygyny should be based on the structural functional roles of marriage in the community and day to day life of the people. It is on the above note that the marriage and divorce bill of Uganda, in which one of the clauses call for legalizing couples that have cohabited for a given time as fully recognized marriage under the law. However, in the bid to protect the institution of marriage, church leaders as well as conservative cultural institutions have rejected this bill. ${ }^{12}$ Yet the same institutions have failed to regulate the psychosocial situations that lead to proper formation of formal marriages. John Kajolya affirms that it is not enough to insist on Christian marriage, but the church needs to further establish structures that will

who married after cohabitation.... Charles B Lwanga and Ishmael Kalule-Sabiti Union Formation and The Timing of A First Birth in Central Uganda: A Decrement Lifetable Analysis (2015, p. 6-7) posted by Population Research and Training Unit, North-West University (Mafikeng Campus), South Africa on website:http://uaps2015.princeton.edu/up loads/150969 Accessed on 28th/6/2017

${ }^{11}$ William Blum, Forms of Marriage: Monogamy Reconsidered (Nairobi: AMECEA Gaba Publications, 1989), 22-27.

${ }^{12}$ Steven Ainganiza, Fort portal Bishops Say No to Marriage and Divorce Bill, (https://ugandaradionetwork.net/story/fortportal-bishops-say-no-to-mariage-and-divorce-bill)2nd April 2013. Accessed on $4^{\text {th }} / 12 / 2019$.

11 | This work is licensed under a Creative Commons Attribution 4.0 International License. 
strengthen the true values of marital union in such circumstances. ${ }^{13}$

Kenneth Hughes observes that the church's legalistic attitude against polygamy is thwarting its mission in the African continent ${ }^{14}$. He observes that the tension between polygamy and monogamy is like the tension between Caucasian and African cultures and should not be limited to religion. Hence the practice should be left to personal conscience and needs. He observes that within the Caucasian culture, there was an evolution from polygamy to monogamy due to societal changes. Therefore, a one-to-many sex relationship, whether it be polygamy, polyandry or concubinage, is part of the social heritage of all peoples ${ }^{15}$. Whenever the actions of men disturb nature's equilibrium in the distribution of the sexes, a sex relationship other than one-to-one develops. Kenneth Hughes affirms that this is true for any community whether African or not. Where the male-female ratio is unbalanced by industry, jobs, trade, wars, diseases or natural factors, we find deviations from normally accepted sex relationships. In this case, polygamy will always come.

Based on the above, sociological factors determine the sexual ethic as a matter of social responsibility. Therefore, African communities too need that natural evolution from polygamy and plural relationships depending on their social cultural realities. This is a critical message to Christian religious leaders in Uganda. These relationships may not be embraced but understood and religious space should be opened to allow participation without discrimination or criminalisation. After all religion in Africa, just like marriage is another anthropological space and problem-solving institution. Therefore, exclusion or intimidation on basis of religious views on monogamy compromises the fundamental nature of religion in society.

\footnotetext{
${ }^{13}$ John B. Ngobi Kalolya, The Heat and Cold Within: Building Stones for a Local Church, (Rome: Tipografica Lebert, 1999) 249.

${ }^{14}$ Kenneth Hughes, The Church and Marriage in Africa, (New York: American Theological Library Association 1972)204.

15 ibid.
}

\section{Continuities and Discontinuities in Polygamy, Plural Relationships and New Models of Relationships}

Since polygamy was and is a sanctioned form of marriage it exists under rules and regulations of the society as well. In some cases, senior wives participated in the search for a new bride who at times was a relative or a friend. Here the older wife or wives participated in training the bride in the dos and don'ts of marriage. Among the Nnobi of Nigeria these were called female husbands ${ }^{16,17}$ while among the Basoga of Uganda these were called ekibeewo. In this case, the bride is got to solve some problems pertaining to provision of labour, progeny, social security and old age. In other circumstances, polygamous men were rich and leaders, so these wives were given to them to bind relations with the ruling families. However, at times this went beyond that, it was to open space for participation and custody in cases such as death of a brother, so another brother takes on the family to take care of the needs of the widow and her children. In other cases of family challenges such as, barren women, sickness and old age, women were kept in the marriage system in order to respect the indissolubility of marriage. In this case, we can argue that polygamy in the traditional African society was for the good of the benefits of marriage. It worked for purposes of human wellbeing and social inclusion.

Furthermore, the uncertainty of life makes people become polygamous to ensure security in child upbringing. One of the local singers in Uganda, Justine Nantume sings a song titled Abasajja muzaaleko ebweru urging men to have children out of wedlock for the sake of social security. Some men have felt a need to have more than one spouse as support to bring up and educate their children in case of an unforeseen problem. Several children in Uganda have been brought up and educated by their half brothers and sisters. Hence polygamy is at

${ }^{16}$ Ifi Amadiume, Male Daughters and Female Husbands: Gender and Sex in African Society, (London: Zed Books Ltd. 1987)162.

${ }^{17}$ Researcher Cultural Research Centre, Celebrating Sanctity of Humanity among the Basoga: Jinja. Marianum Press, 2003.

12 | This work is licensed under a Creative Commons Attribution 4.0 International License. 
times seen as a form of expanding the social capital which plays roles of linking, bridging and bonding.

Not different from the above, currently, polygamy and plural relationships are said to be practiced in order to "diversify offspring". Due to uncertainty, it is believed that one cannot make a total loss if he/she had children with different spouses. From different spouses one may have intelligent, rich, disciplined, healthy, sick and mediocre children which may not be the case if one had one spouse. The practice is also said to mitigate genetic diseases like sickle cell, epilepsy and others. One would argue that with proper family planning, health services and application of science and technology, fears and uncertainty would not be a justification for polygamy and plural relationships now. However, it is important to note here that anthropological reasons overpower all the above because they are deeply rooted in people's world view and can change with time but gradually given the socioeconomic factors on the society.

\section{Structural and Conceptual Differences and World View of the Youth on Polygamy}

Based on the above, the youth are known to be adoptive and change agents in many cultural practices. Considering this, I found a need to interview some of them to establish their opinion as regards polygamy and plural relationships. These were university students taking a course unit of Society, Culture and Development. They were purposively selected for they would understand and appreciate theoretical and practical aspects of the research. These were asked if they would join a polygamous/plural relationship. As observed earlier, out of 35 respondents, only 9 males and 1 female said yes, the rest said no. Moreover, in their responses to subsequent questions as to why plural relationships exist, they gave several justifications as:

- Provision of basic needs to women and children

- For company and social protection during old age (new wives are stronger and give birth to children who serve the elders at home)

- Provision of labour
- Promotes innovativeness because members must devise ways of survival

- For religious purposes e.g., Islam allows four wives

- It is a cultural heritage

- Helps in the prevention or management of hereditary diseases like diabetes, sickle cell anaemia

- Trains good leaders because one from polygamous marriages teaches how to manage diversity

- It is a tool of dominance of men over women

- Caused by popular cultural and media influence e.g., in Nigerian movies where influential people have multiple relations

- Reduces prostitution

- Caused by urbanization where men go looking for jobs, leaving wives in villages, so get new wives in towns

The responses of the youth confirm the anthropological needs that are embedded in the institutions of family and marriage. Here we can deduce that polygamy and plural relationships are not about to end because even the youth also endorse it. These tend to be the agents of change from traditional culture to modernity but based on the situations in the community, they support polygamy. However, reasons to why people should not be in plural relationships were also mentioned as presented below:

- Causes tension in forms of witchcraft accusations, quarrels and domestic violence

- Children do not get enough care and fatherly love

- There is exploitation of women because they tend to take all the responsibility of childcare

- Causes over population

- Causes poverty and lack of basic needs due to limited resources

13 This work is licensed under a Creative Commons Attribution 4.0 International License. 
- Leads to formation of Non-Government Organizations which at times abuse children

- Causes sexually transmitted diseases

- Makes men irresponsible and runners away from family responsibilities

The responses outlined above reveal the tensions attributed to polygamy and plural relationships. However, despite this, the anthropological needs often overpower the tensions and hitherto we have many people joining polygamy and plural relationships. As society gets more advanced in economy and professional life especially among women, a new mode of relationship has come up and this is serial monogamy. This is characterised by a person having one spouse at a time but drops him/her and picks another. In this case, it is normal to find children of the same man or woman in a Reasons for and against serial marriages in Comparison to polygamy

Table 1: Reasons for and against serial marriages in Comparison to polygamy

\begin{tabular}{|c|c|}
\hline For Serial Marriages & Against Serial Marriages \\
\hline $\begin{array}{l}\text { - Serial marriage is better because } \\
\text { there is no occasion for women to } \\
\text { meet and quarrel or practice } \\
\text { witchcraft which may result into } \\
\text { death }\end{array}$ & $\begin{array}{l}\text { - Leads to single mothers and women headed families } \\
\text { - It spreads sexually transmitted diseases } \\
\text { - It is to lacks respect of both men and women in society, } \\
\text { - leads to poverty due to overspending on getting new wife, } \\
\text { - It tortures children and cause tension between children and } \\
\text { stepmothers } \\
\text { - Causes quarrels over wealth } \\
\text { - Shows that a man is incompetent and incapable of loving. } \\
\text { - Men take advantage of women because they can easily get } \\
\text { married } \\
\text { - Polygamy is better because sometimes families teach each other } \\
\text { and cooperate and later turn out to be faithful } \\
\text { - Polygamy is better because children learn their mothers and } \\
\text { fathers physically } \\
\text { - There is more respect in polygamous marriages than serial } \\
\text { monogamy } \\
\text { - Polygamy gives social security because a woman is married to } \\
\text { one man forever }\end{array}$ \\
\hline
\end{tabular}

The responses above reveal the significance of marriage in providing anthropological needs. Serial monogamy is highly detested because it is exclusive in nature. Given the human needs it provides, marriage is pro-life and inclusive and should therefore be indissoluble. It is for this purpose that home but when they have several mothers or fathers. This though appears modern as contrasted to polygamy, it causes several tensions within the family.

A deliberate question was asked to the respondents on what their preference between polygamy and serial marriages would be; many preferred polygamy. On this note, we can deduce that polygamy though detested, will always find its position in an African society. In the contemporary society, polygamy is hardly planned but unavoidably happens. Moreover, the decision for one to join a polygamous union seems a very reflective decision because it is often a consequential option. On the other hand, joining a monogamous marriage seems likely but unfortunately it is at times taken impulsively. This perhaps creates room for polygamy at a later stage. 
people's lives to chance and pity. This has a double negative effect whereby children grow up with insecurity in the hands of a stranger commonly known as "stepmother". It also denies the mother of the children the joy of guiding and guarding them as they grow. Unfortunately, in circumstances of marriage failures, society tends not to sympathize with the so-called stepmother who often is prejudged and regarded as merciless by the society. Under polygamy, each mother takes care of her children. However, in a bid to be approved and socially accepted in the church, there has come incidences of serial monogamy where men have different wives at different times, thus having sets of children. This serial monogamy as indicated above has negative consequences on every member of the family and it is a challenge in domestic relations in families today. Data reveals that in this case, husbands, wives and children suffer the stress.

\section{CONCLUSION}

Polygamy as a form of marriage still has value that has resisted the criticism and impact of Western influence. Discussing polygamy out of anthropological reality has a negative influence on human wellbeing. On this note, it can be concluded that when discussing or making judgments on matters of marriage whether monogamy, polygamy or plural relationships, there is a need to know that the issue deals with human life itself. Therefore, anthropological basis of argument remains paramount over other criterion such as religious and legal laws, which often remain idealistic. As Kajolya argues, these institutions should put emphasis on communities living the values of marriage; which in the process will address issues of legality.

\section{REFERENCES}

Amadiume, Ifi. Male Daughters and Female Husbands: Gender and Sex in African Society. London: Zed Books Ltd, 1987.

Blum, William. Forms of Marriage: Monogamy Reconsidered. (Nairobi: AMECEA Gaba Publications, 1989.
Brinkerhoff, David. and White, Lynn. Essentials of sociology. New York: West Publishing Company, 1989.

Cultural Research Centre, Celebrating Sanctity of Humanity among the Basoga: Jinja. Marianum Press, 2003.

Goody, Jack. Production and Reproduction: A Comparative Study of the Domestic Domains. Cambridge: Cambridge University Press, 1976.

Government of Uganda, The Marriage Act Cap 251(1904) of Uganda, Section 10(d).

Haward, Micheal. and Dunaif-Hattis, Janet. Anthropology: Understanding Human Adaptation. New York: HarperCollins Publishers Inc, 1992.

Hughes, Kenneth. The Church and Marriage in Africa. New York: American Theological Library Association 1972.

Lwanga, Charles. and Kalule-Sabiti, Ishmael. Union Formation and The Timing of a First Birth in Central Uganda: A Decrement Life Table Analysis (2015) posted by Population Research and Training Unit, North-West University (Mafikeng Campus), South Africa on website: http://uaps2015.princeton.edu/uploads/ 150969 Accessed on 28th/6/2017

Ngobi Kalolya, John. The Heat and Cold Within: Building Stones for a Local Church. Rome: Tipografica Lebert, 1999.

Shorter, Aylward. African Culture: An Overview. Nairobi: Pauline Publication Africa, 2001. 